\title{
Analysis of Reporting Period Flexibility
}

\author{
Zuzana Kubašč́kovát, ${ }^{1,}$, Zuzana Juhászová ${ }^{2}$, and Miloš Tumpach ${ }^{3}$ \\ 1,2,3 University of Economics in Bratislava, Faculty of Business Informatics, Department of \\ Accounting and Auditing, Dolnozemská 1, Bratislava, Slovakia
}

\begin{abstract}
Entities take advantage of the possibility of changing the reporting period (to other than the calendar year) because such a change has a rational basis, usually regarding the specific type of business of a particular entity. They are therefore entities that are seasonal in nature respective to their economic activities. As part of the analysis, of the use of the alternative reporting period by the Slovak accounting entities, we present in addition to the number of accounting entities also their area of business to substantiate the reasons why the entity lead to change in the reporting period.
\end{abstract}

\section{Introduction}

The option of voluntary choice of the reporting period, as allowed by current accounting acts and accounting standards, allows entities to choose a financial year other than the calendar year as the reporting period that follows the production process of the entity and thus takes into account the specificities of individual industries and adapts various factors $[1,2]$.

Farmers, foresters, mountain operators, guest houses, hotels, ski resorts, children's parks, indoor pools are largely dependent on a temperate climate zone and it may not always be economically profitable to end the reporting period on 31 December. Taking into account, for example, large shopping chains such as Kaufland, Hypernova and Tesco, for such entities that are busy during Christmas and are preparing their upcoming season in full swing, it is disadvantageous and impractical for them to close their accounts as of December 31, and thus in this hectic period they have to perform reconciliation and closing operations and all the tasks necessary to prepare and publish their financial statements.

One of the possible reasons for changing the reporting period to the financial year other than the calendar year may be the entity's efforts to save its cash for the external processing of financial statements and tax returns, as external entities providing such services are very busy at year-end and higher than in the second half of the year $[3,4,5]$. Entities may negotiate a more advantageous price with external audit entities because it is not the main business season of the audit entity, allowing the entity to calculate with better, more efficient services, including better staffing and external audit entity access, which immediately leads to saving entity's funds $[6,7,8]$.

\footnotetext{
*Corresponding author: zuzana.kubascikova@euba.sk
} 


\section{Methods and Data}

For testing and evaluating data from financial statements we used database available on web page www.registeruz.sk. Financial statements for years 2018-2011 were processed.

Table 1. Research sample

\begin{tabular}{|c|c|}
\hline Year & No. of financial statements \\
\hline 2018 & 219173 \\
\hline 2017 & 208228 \\
\hline 2016 & 198414 \\
\hline 2015 & 190486 \\
\hline 2014 & 186348 \\
\hline 2013 & 166269 \\
\hline 2012 & 90451 \\
\hline 2011 & 96535 \\
\hline
\end{tabular}

Various scientific research methods were applied in writing this paper. Predominant were methods of analysis, synthesis and comparison. Based on the analysis, we have applied theoretical information to problems related to reporting periods from various sources. Then we focused on the target group - accounting entities with other reporting periods than a calendar year, the process of changing the reporting period, the types of accounting entities which use different reporting periods. We used the induction method and a generalization, to characterize the beneficiaries when changing the reporting period and to characterize the advantages and disadvantages in which the entity learned about the alternative choice for the reporting period.

\section{Results and Discussion}

The decision to change the reporting period is taken by economic entities because they can take advantage of such an alternative and the benefits of choosing a financial year as this reporting period outweigh the negatives for the accounting entity.

The following may be considered as advantages of the financial year:

- the financial year is used by those entities with a seasonal dimension to their activities,

- there is no need to prepare different financial statements for the parent company if parent company is using a reporting period other than a calendar year,

- more accurate and truthful business profit calculations for entities of a seasonal nature,

- an effective and fair assessment of the entity's overall business for entities with seasonal activities based on financial and operating information that is consistent with the entity's actual performance,

- lower fees for audit services,

- payment of dividends and shares that better correspond to the entity's actual performance (in seasonal accounting entities),

- fewer errors in the closing operations of the seasonal accounting entities,

- maintaining a true and fair view of the facts that are the subject of the entity's financial statements and providing truthful information about the entity to investors. 
The following may be considered as disadvantages of the financial year:

- it is not so easy to compare financial indicators with other entities from different sectors,

- sometimes there are problems in changing settings in entity information systems.

Entities in the territory of the Slovak Republic may choose their reporting period - calendar year or financial year according to the Accounting Act. How many accounting entities choose the possibility of changing the reporting period we have found in the following graph: We have chosen the years 2011 - 2018 because all the data for 2019 were not yet available (it will only be available in the autumn 2020). When processing the data, we worked with a financial statement published on the website www.registeruz.sk.

Graph 1. Number of accounting entities with another reporting period than calendar year.

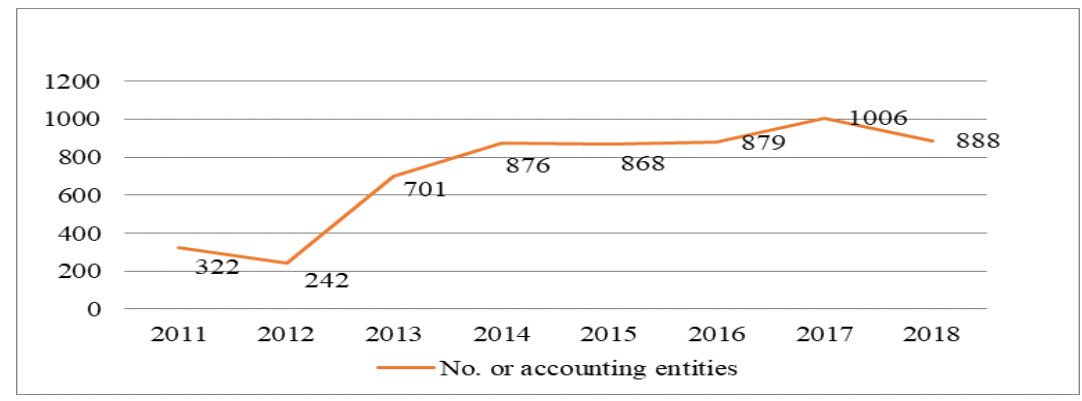

The share of accounting entities that use the fiscal year is extremely low in Slovakia, it is approximately $4.5 \%$ of accounting entities, in the years $2011-2012$ it is only $2.5 \%-3.5 \%$ of entities.

The graph with the number of accounting entities using the fiscal year by type and ownership shows that the fiscal year is used more by international and foreign companies.

Graph 2. Number of accounting entities with another reporting period than calendar year according ownership.

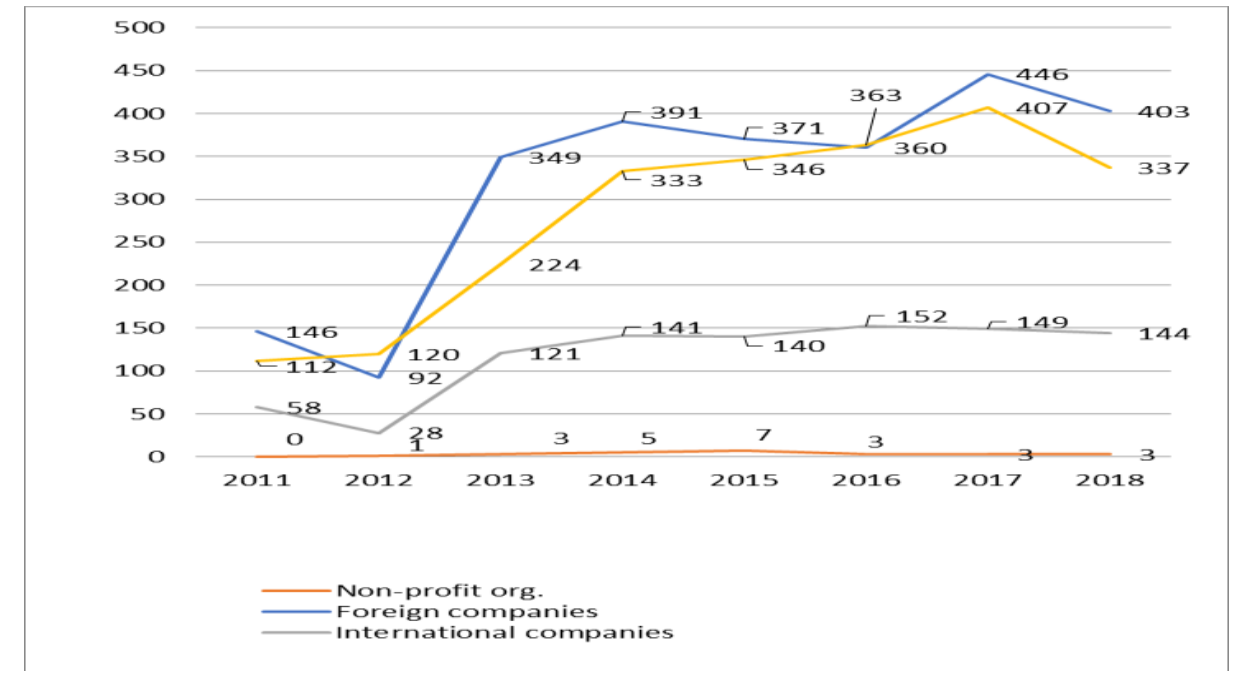

The following table shows the numbers of entities by industry for 2018, the results in individual years are similar. In each sector, the number of such entities is below $1 \%$ of the 
total. Only a slightly higher share is in the automotive industry $(2.9 \%)$, mechanical engineering $(1.26 \%)$, electrical engineering $(1.81 \%)$, chemistry and plastics $(1.06 \%)$.

Table 2. Use the alternatives of the reporting period by Slovak accounting entities by industry

\begin{tabular}{|c|c|c|}
\hline Industry & $\begin{array}{c}\text { No. of accounting } \\
\text { entities }\end{array}$ & $\%$ from of all entities \\
\hline Car industry & 9 & 2,90 \\
\hline Tourism and gastronomy & 21 & 0,16 \\
\hline Transport and logistics & 19 & 0,21 \\
\hline Wood and paper & 6 & 0,25 \\
\hline Electrical engineering & 26 & 1,81 \\
\hline Energy and mining & 4 & 0,31 \\
\hline Finance & 28 & 0,55 \\
\hline Chemistry and plastics & 12 & 1,06 \\
\hline Information technologies & 64 & 2,88 \\
\hline Metal productinon and metallurgy & 26 & 0,59 \\
\hline Retail & 72 & 0,37 \\
\hline Media, publishing and culture & 8 & 0,2 \\
\hline Properties & 48 & 0,31 \\
\hline Clothing and footwear & 3 & 0,24 \\
\hline Agriculture and forestry & 6 & 0,11 \\
\hline Food industry & 13 & 0,63 \\
\hline Law, consulting and accounting & 114 & 0,56 \\
\hline Sale and maintenance of vehicles & 13 & 0,33 \\
\hline Design and engineering & 25 & 0,35 \\
\hline Advertisment & 17 & 0,34 \\
\hline Services & 35 & 0,23 \\
\hline Waste treatment & 1 & 0,12 \\
\hline Brokerage services & 25 & 0,27 \\
\hline Construction industry & 56 & 0,23 \\
\hline Engineering & 26 & 1,24 \\
\hline Education and training & 5 & 0,19 \\
\hline Telecommunications & 5 & 0,75 \\
\hline Wholesale industry & 118 & 0,71 \\
\hline Other production & 1 & 0,11 \\
\hline Development and testing & 12 & 0,4 \\
\hline Health & 70 & 0,71 \\
\hline Total & \multicolumn{2}{|l|}{888} \\
\hline
\end{tabular}

One sector that may benefit from setting a reporting period other than the calendar year is the agricultural sector, whose overall activities, and thus profitability, is due to the rotation of the seasons. From a cost perspective, entities have higher costs during the sowing period, and then the harvest and selling of crops may arise in the following reporting period. The 
agricultural sector is a sector exposed to high risks and uncertainties that are not within the competence of an entity that is unable to accurately determine the evolution of the climate, weather conditions and also changes in prices of agricultural products and commodities on the market. The stages and phases of the industry are subject to a cycle of alternating winter, spring, summer and autumn and corresponding climatic conditions.

If we perceive this topic historically, the state (Slovak Republic) has strictly mandated the calendar year beginning on 1 January and ending on 31 December as the reporting year, but taking into account the alternation of seasons and their impact on the agricultural sector, such behavior is disadvantageous for the state because the economic indicator of gross domestic product does not contain all the appropriate and profitable data necessary to determine the desired level of the macroeconomic indicator of the state for the reporting period. In some economically undeveloped countries, economic production has the strongest impact on a country's economy, so such countries benefit from the flexibility of the reporting period in their favor to increase their gross domestic product.

The attempt to establish a financial year for the agricultural sector implements the requirement to 'count' the sales phase into the reporting year. If an entity wants to meet such a condition, its production process must be less than one year and the products can be resold relatively quickly, most often to animal production for further processing, but also to other industries. In such a specialized holding, it is appropriate to set the beginning of the reporting period at a time when stocks are at a minimum because the minimum stock level reduces the risk of, for example, incorrect inventory counting and inventory valuation. Based on the climatic conditions of our geographical environment the financial year should start on 1 July and end on 30 June. However, taking into account the smaller farmers' business as a private entrepreneur, the start of the 1 July reporting period is economically disadvantageous for them because of the lack of time to carry out the seasonal farmer's work. It is necessary to optimally determine the beginning of the reporting period for the period when the results of the production processes of the previous reporting period can be realistically predicted. For example, if an entity is engaged in the production of oilseed rape as one of the types of winter crops that are sown in the fall, it is convenient for the entity to begin its reporting period on 1 October and end on 30 September the following year.

If an entity chooses an optimal reporting period, it will not only eliminate the risk of miscalculation of its own inventory but if prices fall, the entity must take this into account adjusting its inventory to reduce its profit or loss. Furthermore, it eliminates the risk of unsettled receivables for which the company creates provisions, recognizing in its financial statements the economic benefits of such receivables, which leads to the sustainability of the entity's cash liquidity.

For entities deepening during economic recession, there is an effort to eliminate as many risks as possible from the macroeconomic but also the microeconomic environment. There are a wide variety of tools and methods for such elimination. One of the options is to eliminate risks through the use of accounting policy, by choosing the appropriate reporting period to eliminate accounting and tax risks.

The alternative choice or reporting period cannot be used by entities that are public entities operating under budgetary rules, due to the linking of their budgets and cash flow to the state budget, the budget of municipalities and higher territorial units, which are compiled according to the calendar period. Those that carry on business or perform other selfemployed activity can change a reporting period but they should consider the reasons and consequences of that decision. Changing the reporting period may increase but also decrease the usefulness of the information provided by the financial statements. 'A change 
in the reporting period is justified only if the information, once carried out, leads to greater usefulness and a true and fair view of the business.'

The reasons for applying changes in the reporting period can vary from the need to adapt to the production cycle, through adherence to the accrual principle, to the reconciliation of the reporting period of the subsidiary with the parent company within the consolidated group. Such a change has the advantage of eliminating various risks in terms of the inaccuracy of the data provided in the consolidated financial statements of the consolidated group. Under Slovak legislation, companies that were part of the consolidated group until 2004 had to prepare their financial statements at the end of the calendar year, which however did not correspond to the reporting period of the whole group. Therefore, in many cases, two accounting systems were applied in one accounting entity, one for the purpose of act on accounting and the other for consolidated decision-making purposes. However, such measures greatly complicated the functioning of accounting entities.

In companies with a specific length of production process, there is a problem with allocating revenues to costs. For example, taking into account the construction industry, their costs outweigh the revenues that an entity achieves in a given year or in subsequent years or revenues are based on estimation.x

For entities that decide to change the reporting period it also impacts on the tax period, and therefore entities decide to change their reporting period based on the needs they want to meet.

However, a change in the reporting period can be used to the detriment of the state. Therefore, if an entity which hasmade high profits and is one of the largest entities and whose income tax accounts for a significant portion of its revenue to the state budget, decides to take advantage of the change in reporting period from calendar year to business year to manipulate the amount of income tax paid, and therefore part of the profits would be taxed at the 'old' rate of income tax, the State would reduce by a significant proportion of the income tax received and paid.

\section{Conclusion}

Any company should be aware of the consequences of the use of different reporting periods. This study aims to throw some light on the relevance of choosing a specific reporting period for accounting entities in a European country. However, our analysis indicates that there are some significant advantages when using different income reporting periods to the number of entities using the reporting period another than financial year in Slovakia is still low and no significant year-on-year increase or decrease was recorded.

This paper concludes therefore that, entities should choose a financial year as their reporting period rationally when it comes to entities that are characterized by seasonality agriculture and construction sector, services, entertainment. In an effort to faithfully and truthfully present accounting data, accounting entities change the reporting period as one of the possible tools for eliminating the risks of failing a true and fair view.

\section{Acknowledgments}

This article is an output of the project APVV no. APVV-16-0602 "Enhancement of the relevance of the accounting data in the SR - from expenses to value".

\section{References}


1. Andrejovská, A., Zhodnotenie ekonomickej situácie v obciach pomocou pomerových a absolútnych ukazovatel'ov. Verejná správa a spoločnost' : [vedecký časopis]. - Košice : Fakulta verejnej správy Univerzity Pavla Jozefa Šafárika, roč. 13, č. 1, pp. 102-108 (2012)

2. Canto, O., Gradin, C., Del Rio, C., Poverty statics and dynamics: does the accounting period matter? International journal of social welfare, vol. 15, issue. 3, pp. 209-218 (2006)

3. Krišková, P., Užík, J., Management of audit risk and its impact on the audit of financial statements. Managing and modelling of financial risks : proceedings : 8th international scientific conference : 5th - 6th september 2016, Ostrava, Czech Republic, pp. 460-466 (2016)

4. Lehenchuk, S. F., Valinkevych, N. V., Vyhivska, Irina M., Khomenko, H. Y. The Significant Principles Of Development Of Accounting Support For Innovative Enterprise Financing. International Journal of Advanced Science and Technology, 29(8s), pp. 2282 2289 (2020)

5. Miller, H., Accounting period concept and its effect on management decisions discussion. Journal of accounting research, vol. 4, supplement S, pp. 15-17 (1966)

6. Ondrušová, L., Management decisions leading to ownership transactions. Strategic management : international journal of strategic management and decision support systems in strategic management, vol. 16, no. 3, pp. 18-22 (2011)

7. Pakšiová, R., Janhuba, M., Teória účtovníctva v kontexte svetového vývoja. Bratislava: Iura Edition. (2012)

8. Parajka, B. Are information needs of financial entities served by financial statements in the Slovak Republic. Financial management of firms and financial institutions, pp. 950957 (2015) 